\title{
Mothers' Knowledge and Attitude Regarding Acute Diarrheal Disease at Outpatient Clinic ,Assiut University Children's Hospital
}

\author{
Mohamed , A., A ; Kotb , S., A ; El Magrabi , N., M ; \& EI Sayh , K ., I. \\ Community Health Nursing ., Faculty of Nursing., Assuit University \\ Pediatrics Medicine ., Faculty of Medicine., Assuit University
}

\begin{abstract}
:
Diarrhea occurs world wide and causes $4 \%$ of all deaths. It is most commonly caused by gastrointestinal infections which kill around 2.2 million people globally each year, mostly children in developing countries. In 2008, Egypt prevalence of diarrhea in children aged under five years who receiving Oral Rehydration Solution is $28.4 \%$. Aim of the study was to assess mothers' knowledge and attitude regarding management of acute diarrhea .Subject and Method: cross sectional study was used. It included 600 randomly selected mothers from Assiut University Children's Hospital during 2012. Data Collection from mothers through two tools; first tool was interview questionnaire sheet. It consisted of two parts; first part included Socio-demographic data and the second part mothers' knowledge about diarrhea. The second tool included likert scale to assess mothers' attitude towards diarrhea. Results: The mean age of mothers was $26.08 \pm 5.401$, with no significant relation between mothers' age and their knowledge regarding diarrhea . As regards level of education, it was observed that about than two fifth $(40.7 \%)$ of mothers were illiterate, while only $9.3 \%$ of them were high education. $57.8 \%$ of mothers had satisfactory knowledge of about diarrhea. While, $86.2 \%$ of them had positive attitude towards diarrheal disease. Conclusion: There was a significant difference between mothers' knowledge and their education level. Also, there was a significant difference between numbers of diarrheal episodes and type of feeding. Recommendations: It is very important to provide good sanitation and improvement of housing conditions especially in rural areas.
\end{abstract}

Keywords: Diarrhea; Management; Knowledge; Attitude

\section{Introduction:}

Diarrhea is one of the main causes of morbidity and mortality in children younger than five years of age in developing countries. The average number of episodes of diarrhea per child per year within this age group is 3.2. Twenty one percent of childhood mortality in this age group in these countries is associated with diarrhea. It results in 2.5 million deaths per year. In sub-Saharan Africa, mortality caused by acute diarrhea varies from $1.9 \%$ of all deaths in the Gambia to $37 \%$ in Nigeria, with most of the deaths occurring during the first year of life. (Centers for Disease Control and Prevention CDC, 2009).

Diarrhea related illnesses are generally preventable and easily treatable. Yet 1.5 million children in Africa still die every year, from it 85 children die every day from such diseases in Kenya alone. In Egypt the overall prevalence of diarrhea in children aged under five years who receiving Oral Rehydration Solution (ORS) is $28.4 \%$ while the mortality rate is $11 \%$ (UNICEF/WHO, 2009).

Acute diarrhea lasts less than one week. A child has diarrhea if he has more bowel movements than usual, and if stools are less formed and more watery than usual. Sometimes children with diarrhea have other symptoms, such as fever, loss of appetite, nausea, vomiting, stomach pains, cramps, and blood and/or mucus in the bowel movement (Public Education Advisory Committee, 2008).

Diarrhea can be dangerous if not treated properly because it drains water and salts from the child. If these fluids are not put back quickly, the child may become dehydrated and may need to be hospitalized. Microbes causes diarrhea is easily spread from person to person, and especially from child to child. They usually spread quickly among children who have not learned to use the toilet (Public Education Advisory Committee, 2008).

The specific organisms that cause diarrhea can vary among geographic regions depending on their level of sanitation, economic development, and hygiene. For example, developing countries with poor sanitation or where human waste is used as fertilizer often have outbreaks of diarrhea when intestinal bacteria or parasites contaminate crops or drinking water. In developed countries, including the United States, diarrhea outbreaks are more often linked to contaminated water supplies, person-to-person contact in places such as child-care centers, or "food poisoning" (Rasko etal; 2011).

In general, infections that cause diarrhea are highly contagious. Most cases can be spread to others for as long as someone has diarrhea, and some infections can be contagious even longer. Anything that the infectious organisms come in contact with can become contaminated. This includes toys, changing 
tables, surfaces in bathroom, even the hands of someone preparing food. Kids can become infected by touching a contaminated surface, such as a toilet or toy, and then putting their fingers in their mouths (Schiller, 2007).

When the ability to drink fluids fast enough to compensate for the water loss because of diarrhea is impaired, dehydration can result. Most deaths from diarrhea occur in the very young children whose health may be put at risk from a moderate amount of dehydration.

Nurses play an important role in prevention of diarrhea through Proper hand washing and safe food handling are the most important ways to prevent the spread of organisms that cause diarrhea. They also responsible for educating and supporting mothers with diarrheal disease children during management of diarrhea, also keeping children with right amount of fluids to avoid dehydration (Farthing et al; 2012).

\section{Aim of the study:}

Assessment of mothers' knowledge and attitude towards acute diarrheal disease.

\section{Subject and Method:}

\section{Research design}

Cross sectional research design was used in this study.

\section{Setting of the study}

The study was carried out in Out Patient Clinic at Assiut Children University Hospital.

\section{Sample}

The flow rate in Rehydration Out Patient Clinic during first 6 month in 2011 were 3257 cases. The sample was collected through 6 months (from half of January/2012 to half of July/2012). The researcher attended the clinic two days/ week and the total number was 600 mothers who selected randomly.

\section{Inclusion criteria:}

Mother with Child:

1- More than 2 months of age.

2- No or some dehydration (mild or moderate).

3- Accompanied by mothers (who could provide correct information about feeding, preparation/use of ORS).

4- Duration of diarrhea less than 15 days.

Tools of the study:

Tool (1) structured interview questionnaire: It was designed by the researcher based on relevant literature to assess mothers' knowledge and attitude towards acute diarrhea disease, it included three parts:

Part I: concerned with socio-demographic characteristics of studied sample as mother's age, educational level, occupation, marital status, age of the fathers and fathers' occupation, residence.

Part II: It consisted of mothers' knowledge about as definition, modes of transmission ,causes of diarrhea in children, what is the most common season , complications, definition of dehydration, signs and symptoms, ways of protection and its dangers.

A scoring system was designed for the assessment of knowledge items, a correct response was scored 1 grade and incorrect zero. The score of each item summed-up and then converted into percent score $($ Poor $=$ score $<50 \%$, satisfactory $=$ score $50-65 \%$ and good $=$ score $>65 \%$ ) (El Houfey, 2007).

Part III: likert scale was used to assess mothers' attitude towards acute diarrhea. It included nine statements, eight positive and one negative, with a three point likert scale: agree, uncertain and disagree. These were scored (2, 1 and 0 ) respectively. The scoring was reversed for negative statements. A total score was calculated by summing up and converted into a percent score. The respondent's attitude was considered positive if $60 \%$ or higher and negative if less than 60\% (Ibrahim et al; 2009).

\section{Field of the work}

Data was collected from half of January 2012 to half of July 2012. Each mother was interviewed individually to obtain the necessary information after introducing herself and explaining the purpose of the study. The average time taken for completing each interview was around 10-15 minutes depending on the mothers' response to questions. Every week about 10-15 sheets were finished (two days/ week).

The obtained data were reviewed, prepared for computer entry, coded, analyzed and tabulated to evaluate the difference between the groups under study as regards the various variables. Descriptive statistics (frequencies, percentage, mean and standard deviation) were done using computer program SPSS version 16. Chi square test was used to compare qualitative variables between groups 


\section{Results:}

Table (1): Socio-demographic characteristics of the studied sample with acute diarrheal disease children

\begin{tabular}{|c|c|c|}
\hline Items & No. $(n=600)$ & $\%$ \\
\hline \multicolumn{3}{|l|}{ Mother's age: } \\
\hline$<25$ years & 259 & 43.2 \\
\hline $25-<30$ years & 191 & 31.8 \\
\hline$\geq 30$ years & 150 & 25.0 \\
\hline Mean \pm SD & \multicolumn{2}{|c|}{$26.08 \pm 5.401$} \\
\hline \multicolumn{3}{|l|}{ Residence: } \\
\hline Urban & 191 & 31.8 \\
\hline Rural & 409 & 68.2 \\
\hline \multicolumn{3}{|c|}{ Mother's marital status: } \\
\hline Married & 594 & 99.0 \\
\hline Divorced & 4 & 0.7 \\
\hline Widowed & 2 & 0.3 \\
\hline \multicolumn{3}{|c|}{ Mother's educational level: } \\
\hline Illiterate & 244 & 40.7 \\
\hline Read \& write & 23 & 3.8 \\
\hline Basic education & 99 & 16.5 \\
\hline Secondary & 178 & 29.7 \\
\hline University & 56 & 9.3 \\
\hline \multicolumn{3}{|c|}{ Mother's occupation: } \\
\hline Working & 41 & 6.8 \\
\hline Housewife & 559 & 93.2 \\
\hline \multicolumn{3}{|l|}{ Father's age: } \\
\hline$<25$ years & 63 & 10.5 \\
\hline $25-<30$ years & 144 & 24.0 \\
\hline $30-<35$ years & 179 & 29.8 \\
\hline$\geq 35$ years & 214 & 35.7 \\
\hline Mean \pm SD & \multicolumn{2}{|c|}{$32.27 \pm 6.91$} \\
\hline \multicolumn{3}{|l|}{ Father occupation: } \\
\hline Farmer & 143 & 23.8 \\
\hline Worker & 124 & 20.7 \\
\hline Skilled worker & 135 & 22.5 \\
\hline Free business & 38 & 6.3 \\
\hline Employer & 131 & 21.8 \\
\hline Retired & 4 & 0.7 \\
\hline Not working & 23 & 3.8 \\
\hline Died & 2 & 0.3 \\
\hline \multicolumn{3}{|l|}{$\begin{array}{l}\text { Number of family } \\
\text { members: }\end{array}$} \\
\hline $2-3$ & 173 & 28.8 \\
\hline $4-5$ & 258 & 43.0 \\
\hline$>5$ & 169 & 28.2 \\
\hline
\end{tabular}

Table (2): Mothers ' knowledge about acute diarrhea

\begin{tabular}{|c|c|c|}
\hline Items & $\begin{array}{l}\text { No. }(n= \\
600)\end{array}$ & $\%$ \\
\hline \multicolumn{3}{|l|}{ Definition of diarrhea: } \\
\hline Correct & 478 & 79.7 \\
\hline Incorrect & 122 & 20.3 \\
\hline \multicolumn{3}{|l|}{ Modes of transmission * } \\
\hline Flies & 156 & 26.0 \\
\hline Contaminated food or drink & 167 & 27.8 \\
\hline $\begin{array}{l}\text { Contaminated mother or } \\
\text { child hands }\end{array}$ & 288 & 48.0 \\
\hline \multicolumn{3}{|l|}{ Causes of diarrhea * } \\
\hline $\begin{array}{l}\text { Related to child nutrition } \\
\text { and weaning }\end{array}$ & 205 & 34.2 \\
\hline Related infection & 401 & 66.8 \\
\hline \multicolumn{3}{|l|}{ Other causes: } \\
\hline Antibiotics & 139 & 23.2 \\
\hline Teething & 304 & 50.7 \\
\hline Exposure to air currents & 211 & 35.2 \\
\hline Lack of clean water source & 77 & 12.8 \\
\hline Poor Personal Hygiene & 16 & 2.7 \\
\hline Evil eye & 75 & 12.5 \\
\hline \multicolumn{3}{|l|}{$\begin{array}{l}\text { Which season diarrhea is } \\
\text { common: }\end{array}$} \\
\hline Winter & 112 & 18.7 \\
\hline Spring & 12 & 2.0 \\
\hline Summer & 400 & 66.7 \\
\hline Autumn & 21 & 3.5 \\
\hline Don't know & 55 & 9.2 \\
\hline \multicolumn{3}{|l|}{ Complications of diarrhea: * } \\
\hline Dehydration & 395 & 65.8 \\
\hline Malnutrition & 35 & 5.8 \\
\hline $\begin{array}{l}\text { Decrease body resistance to } \\
\text { disease }\end{array}$ & 149 & 24.8 \\
\hline Death & 6 & 1.0 \\
\hline Don't know & 41 & 6.8 \\
\hline \multicolumn{3}{|l|}{$\begin{array}{l}\text { Ways to protect children } \\
\text { from diarrhea* }\end{array}$} \\
\hline Encourage breast feeding & 446 & 74.3 \\
\hline Improve weaning practice & 58 & 9.7 \\
\hline Good nutrition & 84 & 14.0 \\
\hline Vaccination & 77 & 12.8 \\
\hline $\begin{array}{l}\text { Personal hygiene for } \\
\text { mother and child }\end{array}$ & 189 & 31.5 \\
\hline $\begin{array}{l}\text { Cleanliness of food and } \\
\text { drink }\end{array}$ & 416 & 69.3 \\
\hline Pesticides & 99 & 16.5 \\
\hline $\begin{array}{l}\text { Fight against infectious } \\
\text { diseases }\end{array}$ & 15 & 2.5 \\
\hline Don't know & 36 & 6.0 \\
\hline
\end{tabular}


Table (3):Mothers ' attitude towards acute diarrheal disease

\begin{tabular}{|c|c|c|c|c|c|c|}
\hline \multirow{3}{*}{ Attitude items } & \multicolumn{2}{|c|}{ Agree } & \multicolumn{2}{|c|}{ Uncertain } & \multicolumn{2}{|c|}{ Disagree } \\
\hline & \multicolumn{6}{|c|}{$(n=600)$} \\
\hline & No. & $\%$ & No. & $\%$ & No. & $\%$ \\
\hline 1-Diarrhea is infectious disease & 174 & 29.0 & 199 & 33.2 & 227 & 37.8 \\
\hline $\begin{array}{l}\text { 2-Water source plays an important role in } \\
\text { diarrheal disease occurrence }\end{array}$ & 508 & 84.7 & 70 & 11.7 & 22 & 3.7 \\
\hline $\begin{array}{l}\text { 3-The attention to hygiene reduces diarrhea } \\
\text { episode and it's severity }\end{array}$ & 554 & 92.3 & 30 & 5.0 & 16 & 2.7 \\
\hline $\begin{array}{l}\text { 4-Frequent breast feeding reduces diarrheal } \\
\text { complications }\end{array}$ & 492 & 82.0 & 56 & 9.3 & 52 & 8.7 \\
\hline $\begin{array}{l}\text { 5-Continued breast feeding reduces diarrhea } \\
\text { complications }\end{array}$ & 503 & 83.8 & 57 & 9.5 & 40 & 6.7 \\
\hline $\begin{array}{l}\text { 6-Early introducing foods to children increase the } \\
\text { incidence of diarrhea }\end{array}$ & 389 & 64.8 & 125 & 20.8 & 86 & 14.3 \\
\hline $\begin{array}{l}\text { 7-Giving the baby ORS compensates the loss of } \\
\text { salts and minerals }\end{array}$ & 426 & 71.0 & 169 & 28.2 & 5 & 0.8 \\
\hline $\begin{array}{l}\text { 8-Increasing fluids during a diarrhea episode } \\
\text { reduces the incidence of dehydration }\end{array}$ & 389 & 64.8 & 60 & 10.0 & 151 & 25.2 \\
\hline $\begin{array}{l}\text { 9-The first step to treat diarrhea is giving } \\
\text { medication }\end{array}$ & 416 & 69.3 & 46 & 7.7 & 138 & 23.0 \\
\hline
\end{tabular}

Table (4): Relation between number of diarrheal episodes and type of feeding in response to acute diarrheal disease $(n=600)$

\begin{tabular}{|c|c|c|c|c|c|c|c|c|}
\hline \multirow{3}{*}{$\begin{array}{l}\text { No. of diarrheal } \\
\text { episodes }\end{array}$} & \multicolumn{8}{|c|}{ Type of feeding } \\
\hline & \multicolumn{2}{|c|}{ Breast feeding } & \multicolumn{2}{|c|}{ Artificial feeding } & \multicolumn{2}{|c|}{ Both } & \multicolumn{2}{|c|}{ Total } \\
\hline & No. & $\%$ & No. & $\%$ & No. & $\%$ & No. & $\%$ \\
\hline None & 219 & 46.0 & 18 & 29.5 & 33 & 52.4 & 270 & 45.0 \\
\hline Once & 216 & 45.4 & 40 & 65.6 & 22 & 34.9 & 278 & 46.3 \\
\hline Twice or more & 41 & 8.6 & 3 & 4.9 & 8 & 12.7 & 52 & 8.7 \\
\hline Total & 476 & 100.0 & 61 & 100.0 & 63 & 100.0 & 600 & $\mathbf{1 0 0 . 0}$ \\
\hline P-value & & & & & & & & \\
\hline
\end{tabular}

${ }^{(*)}$ There is significant difference

Table (5): Relation between mothers' knowledge and socio-demographic characteristics according to their response to acute diarrheal disease

\begin{tabular}{|c|c|c|c|c|c|c|c|}
\hline \multirow{3}{*}{ socio-demographic data } & \multicolumn{6}{|c|}{ Level of knowledge } & \multirow{3}{*}{ P-value } \\
\hline & \multicolumn{2}{|c|}{$\begin{array}{c}\text { Poor } \\
(n=168)\end{array}$} & \multicolumn{2}{|c|}{$\begin{array}{c}\text { Satisfactory } \\
(n=347)\end{array}$} & \multicolumn{2}{|c|}{$\begin{array}{c}\text { Good } \\
(n=85)\end{array}$} & \\
\hline & No. & $\%$ & No. & $\%$ & No. & $\%$ & \\
\hline \multicolumn{7}{|l|}{ Age: } & \multirow{4}{*}{0.531} \\
\hline$<25$ years & 79 & 30.5 & 146 & 56.4 & 34 & 13.1 & \\
\hline $25-<30$ years & 45 & 23.6 & 118 & 61.8 & 28 & 14.7 & \\
\hline$\geq 30$ years & 44 & 29.3 & 83 & 55.3 & 23 & 15.3 & \\
\hline \multicolumn{7}{|l|}{ Educational level: } & \multirow{6}{*}{$0.006^{*}$} \\
\hline Illiterate & 81 & 33.2 & 140 & 57.4 & 23 & 9.4 & \\
\hline Read \& write & 5 & 21.7 & 14 & 60.9 & 4 & 17.4 & \\
\hline Basic education & 31 & 31.3 & 56 & 56.6 & 12 & 12.1 & \\
\hline Secondary & 43 & 24.2 & 105 & 59.0 & 30 & 16.9 & \\
\hline University & 8 & 14.3 & 32 & 57.1 & 16 & 28.6 & \\
\hline
\end{tabular}




\begin{tabular}{|c|c|c|c|c|c|c|c|}
\hline \multirow{3}{*}{ socio-demographic data } & \multicolumn{6}{|c|}{ Level of knowledge } & \multirow{3}{*}{ P-value } \\
\hline & \multicolumn{2}{|c|}{$\begin{array}{c}\text { Poor } \\
(n=168)\end{array}$} & \multicolumn{2}{|c|}{$\begin{array}{c}\text { Satisfactory } \\
(n=347)\end{array}$} & \multicolumn{2}{|c|}{$\begin{array}{c}\text { Good } \\
(n=85)\end{array}$} & \\
\hline & No. & $\%$ & No. & $\%$ & No. & $\%$ & \\
\hline \multicolumn{7}{|l|}{ Occupation: } & \multirow{3}{*}{0.212} \\
\hline Working & 13 & 31.7 & 19 & 46.3 & 9 & 22.0 & \\
\hline Housewife & 155 & 27.7 & 328 & 58.7 & 76 & 13.6 & \\
\hline \multicolumn{7}{|l|}{ Residence: } & \multirow{3}{*}{0.722} \\
\hline Urban & 57 & 29.8 & 106 & 55.5 & 28 & 14.7 & \\
\hline Rural & 111 & 27.1 & 241 & 58.9 & 57 & 13.9 & \\
\hline
\end{tabular}

There is a significant difference

Figure(1) Positive versus negative attitude of studied sample towards acute diarrheal disease

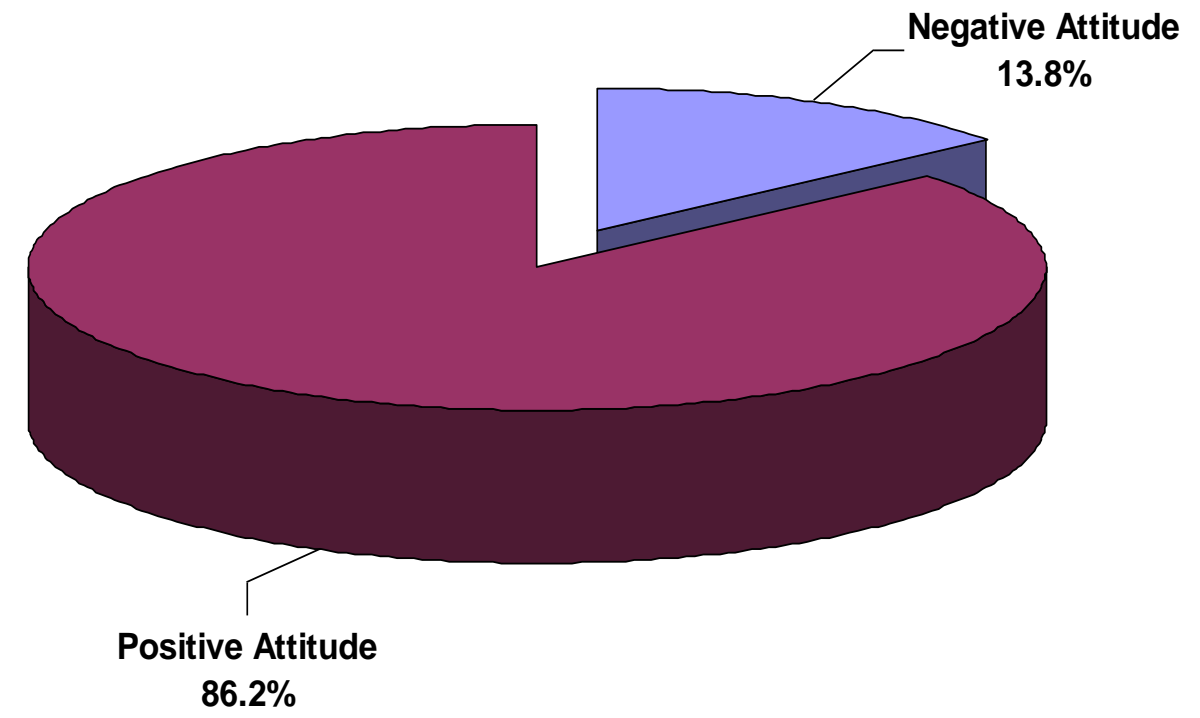

Figure (2): Correlation between mothers' knowledge and attitude towards acute diarrheal disease

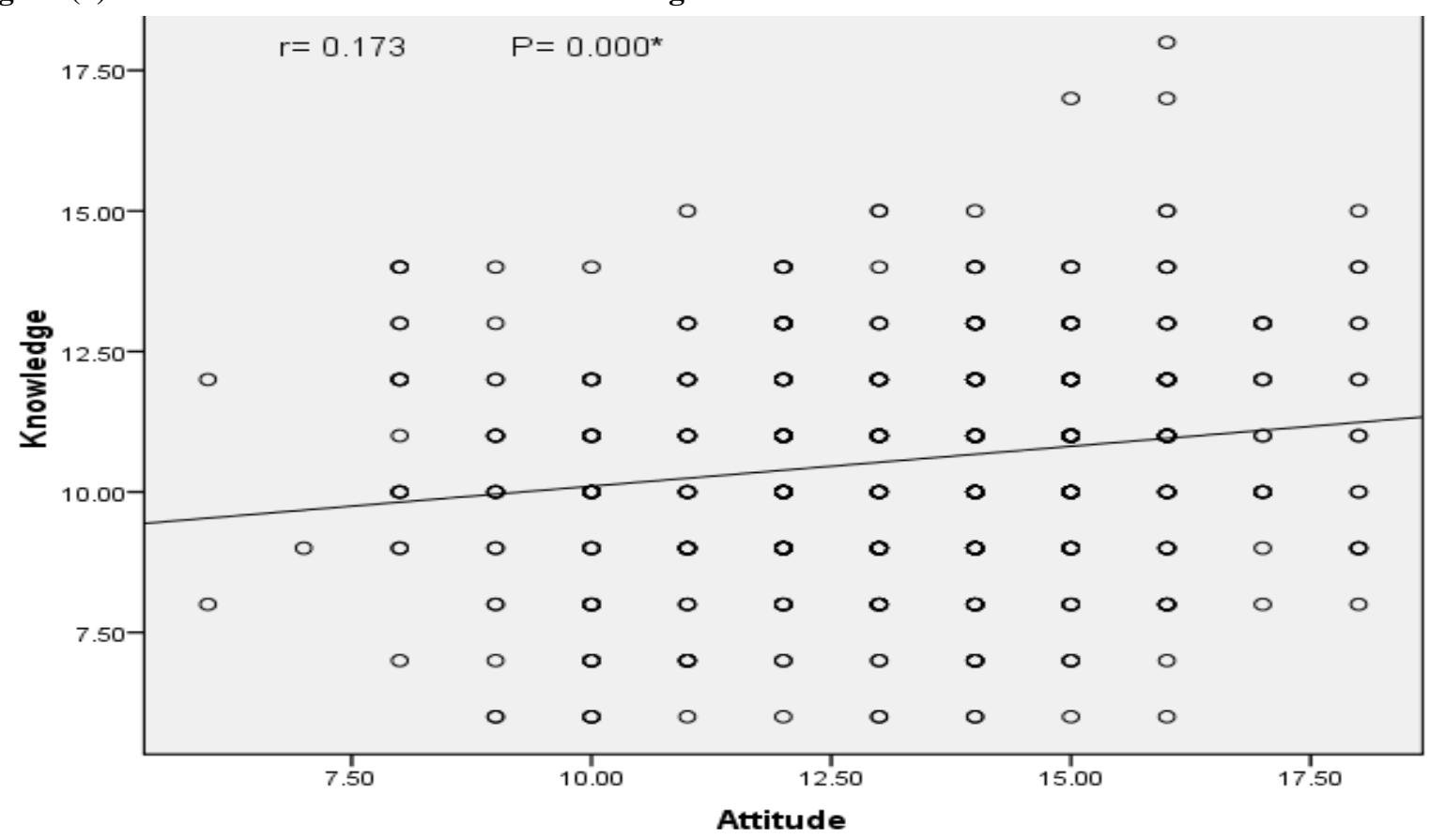


Table (1): shows socio-demographic characteristics of studies sample with acute diarrheal disease children. More than two fifth (43.2\%)of studied mothers aged less than 25 years. The Mean age \pm SD was $26.08 \pm 5.401$. According residence, slightly more than two third $(68.2 \%)$ of them live in rural area, while (31.8\%) live in urban area.

With regards level of education, it was observed that about two fifth $(40.7 \%)$ of mothers were illiterate, while only $(9.3 \%)$ of them were high education. According to occupation of mothers, it was estimated that the majority $(93.2 \%)$ of participated mothers were housewives. Regarding to fathers' age, it was noticed that $(35.7 \%)$ of fathers were more than 35 years. Regarding fathers' occupation, it was cleared that $(23.8 \%)$ of fathers were farmers. With regard to number of family members, the result revealed that two fifth $(43 \%)$ of studied families were from 4 to 5 members.

Table (2): Mothers' knowledge about acute diarrhea. Regarding definition of diarrhea, it was clear that more than three quarter $(79.7 \%)$ of mothers gave correct answer. In addition, (48\%) of participated mothers stated that contaminated mother or child hands are the modes of transmission of diarrhea, while $(26 \%$ )of them reported flies. Regarding to causes of diarrhea in children, about two third $(66.8 \%)$ of mothers stated that infection. While, $(34.2 \%)$ of them said that child nutrition and weaning practice and $(50.7 \%)$ stated that teething cause diarrhea.

According to the common season of diarrhea, it was noticed that $(66.7 \%)$ of mothers said summer season. As regarding to complications of diarrhea, it was found that $(65.8 \%, 5.8 \%, 24.8$ and $1 \%$ ) of mothers stated that dehydration, malnutrition, decrease body resistance to disease and death respectively. Also this table shows ways to protect children from diarrhea and its dangers. About three quarter (74.3\%) of mothers reported encourage breast feeding, while only $(2.5 \%)$ of them stated that fighting against infectious diseases.

Table (3): Mothers' attitude towards acute diarrheal disease. It was noticed that more than one third (37.8\%) of mothers disagreed on diarrhea is infectious disease, while most of them (92.3\%) agreed that the attention to hygiene reduces diarrhea episode and its severity.

Also, the table shows that the majority $(82 \%)$ of participated mothers agreed on frequent breast feeding reduces diarrheal complications. Unfortunately, it was clear that $(6.7 \%)$ of mothers disagreed on continued breast feeding reduces diarrhea complications, while less than fifth $(10 \%)$ of them uncertain about increasing fluids during a diarrhea episode reduces the incidence of dehydration. Finally, it was observed that more than three fifth $(69.3 \%)$ of mothers agreed that the first step to treat diarrhea is giving medication.

Table (4): refers the relation between number of diarrheal episodes and type of feeding responses to acute diarrheal disease. The table shows that there is a significant difference between numbers of diarrheal episodes and type of feeding $(\mathrm{P}=0.01)$. More than two fifth $(46 \%)$ of breast feeding children hadn't diarrheal episodes, while about two third $(65.6 \%)$ of artificial feeding children had once episode of diarrhea. While $12.7 \%$ of children with both types of feeding had twice or more episodes.

Table (5): Relation between mothers' knowledge and socio-demographic characteristics. It revealed that there is a significant statistical difference between mothers' knowledge and their educational level. It was found that less than fifth $(13.1 \%)$ of studied mothers aged $<25$ years had good knowledge, while $23.6 \%$ of mothers aged $25-<30$ years had poor knowledge and more than one quarter (29.3\%) of mothers aged $\geq 30$ years had poor knowledge. With regards to the level of education, it was observed that only $9.4 \%$ of illiterate mothers had good knowledge, while $14.3 \%$ of highly educated mothers had poor knowledge.

Figure (1): Illustrates Positive versus negative attitude of studied sample towards acute diarrheal disease. The majority (86.2\%) of mothers had positive attitude towards acute diarrhea.

Figure (2): Shows that there is a positive correlation between mothers' knowledge and attitude towards diarrheal disease.

\section{Discussion:}

Each child under 5 years of age experiences an average of three annual episodes of acute diarrhea. Globally in this age group, acute diarrhea is the second leading cause of death (after pneumonia), and both the incidence and the risk of mortality from diarrheal diseases are greatest among children in this age group, particularly during infancy. This decline especially in developing countries is largely due to the use of early and appropriate oral rehydration therapy with oral rehydration solution being its main component as well as improved nutrition and water sanitation measures (Al-Atrushi, et al, 2012).

Regarding age groups of mothers, result of present study revealed that more than quarter of the participated mothers aged 30years or more and the mean of mothers' age were $(26.08 \pm 5.401)$. Similar finding were reported by (Monazea, 2003), who conducted a prospective field study of health services utilization pattern of children with diarrhea in Assiut 
city and reported the same age which range 30 years or more with the mean of mothers' age were $27.02 \pm 6$. At the same this results were supported by( Ansari, et $\boldsymbol{a l}, 2011$ ) who carried out a study in Nepal to survey mothers' knowledge about childhood diarrhea and its management and reported the same result.

According to mothers' education, it was estimated that only $9.3 \%$ of participated mothers were highly educated, similar finding were reported by (Monazea, 2003), who stated that mothers with high education were about $9.3 \%$. On other hand these results disagreed with (Sultana, 2010), who carried out a study to assess knowledge and attitude of mothers regarding oral rehydration salt and found that the majority of mothers were highly educated.

The results of present study revealed that there was significant relation between mothers' knowledge and their education. This result disagreed with (Ghasemi, et al, 2013, who found that the education of the mothers didn't reveal significant statistical difference to their knowledge about diarrhea. Also, this finding was contradicted with Ansari, et al, 2011, who found that there was no statistical significant difference between mothers' knowledge and their education.

Regarding mothers' occupation, it was estimated that $93.2 \%$ of mothers were housewife. This result is in the same line with results of Monazea, 2003 and Sultana, 2010, who found that the majority of participated mothers were housewives. The result of present study cleared that there was no statistical significant difference between mothers' knowledge and their occupation. This result is in contrast with Ghasemi, et al, 2013, who found that the knowledge of the mothers had statistical significant difference with their occupation.

According to residence, the present study showed that diarrhea more prevalent among rural (68.2\%) than urban $(31.8 \%)$. It may be explained by low socioeconomic status, poor hygienic practices among the child family members and mothers' low educational level. These factors are common in rural area. This finding was in the same line with Banerjee, et al, 2004, who conducted a study on diarrhea management among under fives in Indian and found that prevalence of diarrhea was $68.3 \%$ in rural areas in contrast to that reported in urban areas which was $31.7 \%$.

Concerning mothers' knowledge about acute diarrhea mode of transmission, the present study releaved that $48 \%$ of participated mothers stated that contaminated mother or child hands, while $26 \%$ of them reported flies. These results agreed with Ameer, et al,2008 who reported that $30.1 \%$ handling food without washing hands, $29.3 \%$ direct contact with infected flies and $22.8 \%$ failing to wash hands after handling feces.
According to mothers' attitude towards acute diarrhea, the present study revealed that the majority $(86.2 \%)$ of participated mothers had positive attitude, while less than fifth $(13.8 \%)$ of mothers had negative attitude. It may be explained by that most of participated mothers were from rural areas where extended family most found and mothers took experience from family or it may be related to spread of mass media which concerning for diarrhea and it's management. These results agreed with Ansari, et al, 2012, who reported that most of the mothers' attitudes were positive.

\section{Conclusion and Recommendations:}

Study showed that mothers had satisfactory knowledge about diarrhea, while they had positive attitude about it. There was a significant difference between mothers' knowledge and their education level. Moreover, there was positive correlation between mothers' knowledge and their attitude towards diarrhea. So the study recommended that nutritional educational program about diarrhea should be implemented for mothers in different community health services . Good sanitation and improvement of housing conditions especially water resources in rural areas. Posters should be posted in outpatient clinic to enhance the practice used in management of diarrheal disease. Films and audio-visual materials about the practical procedures could be useful in teaching mothers required skills as Oral rehydration solution preparation and how to give to their children.

\section{References:}

1. Ameer A, Al-Hadi A and Abdulla M, (2008): Knowledge, attitudes and practices of Iraqi mothers and family child-caring women regarding breast-feeding. East Medical Health Journal, 14(5): Pp 14-1003.

2. Al-Atrushi A, Saeed S and Yahya S, (2012): Knowledge, attitude and practice of mothers to words oral rehydration therapy in duhok Isra Medical Journal 4(3):1-7.

3. Ansari M, Ibrahim $M$ and Shankar P, (2011): Survey of mothers' knowledge about childhood diarrhea and its management among a marginalized community of Morang, Nepal, Australas Med J; 4(9):474-479.

4. Banerjee B, Hazra $S$ and Bandyopadhyay D, (2004): Diarrhoea management among under fives. Indian Pediatric. 2004; 41 (3): 60-255.

5. Centers for Disease Control and Prevention, (2009): Investigation Update: Outbreak of Salmonella Typhimurium Infections, http://www.cdc.gov/salmonella/typhimurium/up date.html 
6. El Houfy A, (2007): Knowledge and Practices of Dental Health Care Providers toward Crossinfection Control Measures in Assuit. Master Thesis. Faculty of Nursing Assuit University

7. Farthing $M$, Salam $M$, Lindberg $G$, Dite $P$, Khalif I, Lindo E, Ramakrishna B, Goh $K$, Khan A,Thomson A, Krabshuis $J$ and LeMair $A$, (2012): Acute diarrhea in adults and children: a global perspective, World Gastroenterology Organisation Global Guidelines,Pp1-24.

8. Ghasemi A, Talebian A, Alavi N and Mousavi $G$, (2013): Knowledge of Mothers in Management of Diarrhea in Under-Five Children, in Kashan, Iran ,Nursing and Midwifery Studies, 1(3): 62-158.

9. Ibrahim H, Ahmed A, El-Aziz M and Hussien A(2009): Nutritional and exercise habits for prevention of osteoporosis among female adolescents in Assiut City secondary school, the new egyptian journal of medicine ,41(4) :346356.

10. Monazea A, (2003): A prospective field study of health services utilization pattern of children with diarrhea in Assuit city, doctoral thesis faculty of medicine, Assuit University, Pp 64112.

11. Public Education Advisory Committee, (2008) : Dehydration and diarrhea in children: Prevention and treatment, http://www.caringforkids.cps.ca/handouts/dehyd ration_and diarrhea

12. Rasko D, Webster D and Sahl J, (2011): Origins of the E. coli strain causing an outbreak of hemolytic-uremic syndrome in Germany. North England Journal of Medicine, 365(8): 17- 709.

13. Schiller L, (2007): Management of diarrhea in clinical practice: strategies for primary care physicians". Rev Gastroenterology Disorder, 7 (3): 27-38.

14. Sultana A, Riaz R, Ahmed $R$ and Khurshid $R$, (2010): Knowledge and Attitude of Mothers Regarding Oral Rehydration Salt, Journal of Rawalpindi Medical College (JRMC):14(2): 109-111.

15. UNICEF \& WHO, (2009): Diarrhea, Why children are still dying and what can be done, Pp1-58, http://www .unicef. org/media/files /Final_Diarrhoea_Report_ October_2009_final.pdf. 